\title{
Transforming the Insider-Outsider \\ Perspective: Postcolonial Fiction from \\ the Pacific
}

Sandra Tawake

$\mathrm{U}_{\mathrm{n}}$

til I970, most of the fiction about the Pacific and Pacific Islanders was written by people living outside the Pacific. It was written from a Eurocentric perspective that depicted Pacific Islanders as exotic, peripheral, "noble," heroic, primitive. That fiction tended to marginalize Pacific Island peoples and to present them in the roles of spectators and objects of European desires. Samoans, Tahitians, Maori, and Hawaiians depicted in the works of such writers as W Somerset Maugham, James Michener, Herman Melville, and Pierre Loti represent secondary, minor characters in what are now described as colonial narratives of the islands. Although some of the writers' Pacific characters reveal attempts to create a more active, complex indigenous presence, most central roles were reserved for boat captains, naval officers, colonial officials, missionaries, and the like. Paul Sharrad, in his Readings in Pacific Literature (1993), claimed that this early writing about the Pacific was deemed subliterary for being too involved with "artless yarning," travelogues, and popular or children's romances. However, Sharrad (I993, I) named several works that are usually identified as marking the beginning of an "authentic" ${ }^{1}$ Pacific literature: Albert Maori Kiki's autobiography, Kiki: Ten Thousand Years in a Lifetime (I968); Vincent Eri's novel, The Crocodile (r970); Witi Ihimaera's and Patricia Grace's story collections, Pounamu, Pounamu (I972), and Waiariki (I975); and Albert Wendt's novel, Sons for the Return Home (I973). In Sharrad's terms Pacific Literature came into its own as a field of literary study in the I980s, when Albert Wendt edited and published a South Pacific anthology, Lali (I980); when Subramani wrote a critical study, South Pacific Literature: From Myth to Fabulation (I985); and when Keri Hulme's The Bone People was awarded the Booker Prize (I985).

The Contemporary Pacific, Volume I2, Number I, Spring 2000, I55-I75

(C) 2000 by University of Hawai'i Press 
In those early "authentic" works of fiction emanating from the Pacific, Pacific peoples were not presented as homogeneous, stable, standardized-as colonial writers often conceived them. Western writers and anthropologists in the past had seemed to assume that members of "other" societies lacked free will; that their cultures were homogeneous; and that they had few choices. These writers further assumed that people in the western world were heterogeneous-able to exercise free will; fluidity and discontinuity were central; they were free to "craft" their lives.

These works of fiction by some of the best-known writers from the Pacific Islands were read as evoking life in the Pacific as it was actually lived, viewed through the eyes of those who lived it. Those works were interpreted as insider representations of island rhythms and smells, anguish and loss. They were described by Albert Wendt (1995) as reflecting demographic and political changes that have taken place in the Pacific, documenting the complexity of life and the struggles to survive through insiders' eyes.

\section{“Authentic" Fiction from the Pacific: Insider-Outsider Perspective}

Best known among the early writers from the Pacific are Albert Wendt (Samoan), Patricia Grace (Maori), Witi Ihimaera (Maori), and Keri Hulme (Maori). Important works of fiction by these writers have been read as expressing conflicts within central characters that epitomize an insider-outsider clash of values and perspectives. In expressing the struggles of their Pacific Island characters, these writers constructed their own realities and maintained a sense of coherent experience, using a metaphor of characters who come to see themselves through the eyes of outsiders, who experience perhaps disease (Keri Hulme's The Bone People), perhaps heaviness of spirit and a drift towards death (Patricia Grace's Cousins and "Parade"), but who ultimately reject seeing themselves through outsiders' eyes and turn away from sterility and emptiness, then experience healing. A number of characters in fiction from the Pacific during this period were depicted as finding renewal and new growth and strength as a result of seeing with their own eyes. Thus, a way of looking at the world through indigenous eyes came to replace what was being discredited as an invalid colonial vision. 


\section{"Parade” by Patricia Grace}

An early Patricia Grace story, "Parade" in Waiariki (1975, 8I), exemplifies this metaphor for the seductive proposition that a literature written from the inside (that is, presenting the world through the eyes of Pacific Islanders) provides a construction of reality that can withstand critical scrutiny and can correct the vision of the Pacific imposed by outsiders. The underlying implications of that proposition are that literature written by non-Pacific Islanders is colonialist, demeaning, inauthentic; and literature written by Pacific Islanders is expressive of authentic culture, historical agency, and social reality.

In Grace's story, the main character, Matewai, has returned to her rural Maori home for the annual week of carnival in response to a letter from her auntie. Having gone into the bush late in the week with her cousins early one morning to cut fern and flax to decorate the truck and platform where she will dance later that day, Matewai feels soothed and able to put aside the heaviness of spirit that has unaccountably come upon her. She sees strength in the spears of flax and recognizes that the flax blooms are swollen with seedpods that will burst and yield new growth and strength - the heaviness of each pod putting forth new life.

It was soothing to follow with my eyes the spreading circles of fern patterning the hills' sides.... It was good to look into the open throated flax blooms with their lit-coal colours, and to put a hand over the swollen black splitting pods with the seed heavy in them.

And I thought of how each pod would soon cast aside its heaviness and become a mere shell, warped and empty, while that which had been its own heaviness would become new life. New growth and strength. (Grace 1975a, $8 \mathrm{I})$

Grace implies that the seedpods serve as a symbol of Matewai's transformation when she uses the same language to describe what happens to Matewai that she has used to describe what happens to the flax. In her time away from home, Matewai has come to see herself and other Maori as outsiders see them. She has lost the innocence and unselfconsciousness that she once shared with her young cousins. She has lost her own eyes and taken up the eyes of outsiders. That change in perspective is represented as being responsible for Matewai's heaviness of spirit, her sense that she is an object to be stared at. 
As we carried the bundles of fern and flax ... I was able to feel that tomorrow, the final day of the carnival, would be different from the ones recently passed when realisation had come to me, resting in me like stone. . . .

I tried not to think. Tried not to let my early morning feelings leave me. Tried not to know that there was something different and strange in the people's reaction to us. And yet I knew this was not something new and strange, but only that during my time away from here my vision and understanding had expanded. I was able now to see myself and other members of my race as others see us. And this new understanding left me as abandoned and dry as an emptied pod of flax that rattles and rattles into the wind. (Grace I975, 8I, 84 )

Like the seedpods of the flax, Matewai is heavy; she feels burdened by what she perceives as the Pakeha view of herself and her people. During the parade, Matewai thinks of her uncle Hirini and cousin Hoani as a pair of circus clowns as they performed traditional Maori actions with the taiaha (long weapon of hardwood). She imagines that the enjoyment on the faces in the crowd as her people sing and dance is like the enjoyment people feel in zoos or circuses. Matewai feels as if she and other Maori have been turned into mere spectacles, like animals in cages or exhibits in a museum. And the consciousness Matewai has of being turned into an object leaves her feeling emptied and sterile.

Animals in cages to be stared at. This one with stripes, this one with spotsor a trunk, or bad breath, the remains of a third eye. Talking, swinging by the tail, walking in circles, laughing, crying, having babies.

Or museums. Stuffed birds, rows of shells under glass, the wing span of an albatross, preserved bodies, shrunken heads. Empty gourds, and meetinghouses where no one met any more.

I kept thinking and trying not to think, "Is that what we are to them?" Museum pieces, curios, antiques, shells under glass. A travelling circus, a floating zoo. People clapping and cheering to show that they know about such things. (Grace 1975,85 )

When it is time for her to dance, Matewai does not want to take her place on the platform that has been erected for her dance at the carnival. She responds to Granny Rita's "Go. Take your place," with "I think I'll watch this time Nanny." "They think that's all we're good for," she says. "A laugh and that's all. Amusement. In any other week of the year we don't exist. Once a year we're taken out and put on show, like relics" (Grace I975, 88). 
The answer to Matewai's sadness, and the heaviness that she feels must be cast off, comes into the silence following her expression of the outsider perspective; and it comes in Granny Rita's response to her statement that Maori are like relics.

And silence.

Silence with people laughing and talking.

Silence with the singing lifting skyward, and children playing.

Silence. Waiting for them to say something to me. Wondering what they would say.

"You grow older, you understand more," Granny Rita said to me.

Silence and waiting.

"No one can take your eyes from you," she said. Which is true.

Then old Hohepa, who is bent and sometimes crabby said, "It is your job, this. To show others who we are."

And I sat there with them for a long time. Quiet. Realising what had been put upon me. Then I went toward the group and took my place, and began to stamp my feet on to the cracked earth, and to lift my voice to the sun who holds the earth's strength within himself. (Grace I975, 88)

In the story, when Matewai casts off the outsider perspective that has been weighing her down, she experiences new energy and renewal. When she affirms Granny Rita's observation that no one could take her eyes from her, Matewai resumes using her own eyes and then joins her people. In this act of joining her people to show others who they are, Matewai frees herself from the heaviness of spirit she had assumed when she began to view her people from the perspective of outsiders. The story ends as a truck wends its way along, opening gates and closing gates, bearing Matewai and her family who have moved close together against the small chill that evening has brought. The last paragraph of the narrative shows Matewai drawing in a big breath "of sea and air and land and people." Filling her lungs with "past and present and future" and feeling a new strength course through her as she lifts her voice to sing, Matewai feels the others join with her.

The final vision that Grace offers in this story seems to affirm Matewai's rejection of seeing with the eyes of outsiders and the rightness of seeing with her own eyes. The vision in Grace's story is congruent with Sharrad's perspective that "authentic" Pacific writing emanates from the vision of Pacific Island peoples.

The metaphor that Grace elaborates in "Parade" suggests that power and new life are consequences of seeing the Pacific through the eyes of its 
own people. The recurrence of that same metaphor in other works of fiction by indigenous Pacific writers calls attention to the power of that writing to reconstruct Pacific histories, to rewrite Pacific geographies, and to create Pacific realities that can overwrite perspectives imposed by outsiders.

\section{Contemporary Criticism: Postcolonial Theory}

New writing from the Pacific in the I990s-by Alan Duff, Sia Figiel, John Pule, and Witi Ihimaera-has altered the landscape yet again. These new works, and indeed earlier works from the Pacific, must be examined from a more complex perspective than that of a simplistic insider-outsider dichotomy. Prominent postcolonial critic Trinh T Minh-ha has commented on such a simplistic dichotomy in the context of filmmaking:

For there can hardly be such a thing as an essential inside that can be homogeneously represented by all insiders; ... questions like "How loyal a representative of his/her people is s/he?" (the filmmaker as insider), or "How authentic is his/her representation of the culture observed?" (the filmmaker as outsider) are of little relevance. When the magic of essences ceases to impress and intimidate, there no longer is a position of authority from which one can definitely judge the verisimilitude value of the representation. ... "I" is not unitary, culture has never been monolithic.... Differences do not only exist between outsider and insider-two entities-they are also at work within the outsider or the insider-a single entity. (Minh-ha I995, 21 8)

Who possesses a real world island voice? Who is insider? No straightforward simple answer is possible. The reality of contemporary Pacific writers' experience illustrates the complications inherent in claiming privilege for their voices because they are native. Not a single one of the writers of recent fiction from the Pacific is positioned "inside" a single fixed cultural community. Albert Wendt was born in Samoa, educated in New Zealand, married to a Pakeha (Caucasian) New Zealander for twentyfive years, served for a number of years on the faculty at the University of the South Pacific in Fiji and now holds a chair at the University of Auckland. Witi Ihimaera, a New Zealand Maori, was educated in New Zealand, was married for more than twenty years to a Pakeha New Zealander, and was a career diplomat with the New Zealand Ministry of Foreign Affairs, serving as New Zealand consul in New York and Coun- 
sellor (Public Affairs) at the New Zealand Embassy in Washington DC. $\mathrm{He}$ is now at the University of Auckland. Alan Duff was born in New Zealand of a Maori mother and a Pakeha father. Sia Figiel was born in Samoa, educated in Western Samoa, New Zealand, and the United States, spent several years in Germany, and has recently been living in Fiji. John Pule was born in Niue of Niuean parents who emigrated to New Zealand when he was a child. Keri Hulme is by blood one-eighth Maori, but in her own accounting "by heart and mind" a member of the Maori community in New Zealand. The Indo-Fijian writers Subramani, Satendra Nandan, Sudesh Mishra, and Raymond Pillai have mixed cultural and linguistic backgrounds by virtue of being born in Fiji to parents who were children of indentured plantation workers from India. In no real sense can any of these writers be considered simply an insider or native voice who speaks for Pacific Islanders, since the category Pacific Islander is not clear-cut or capable of a definition that allows people to be assigned to one and only one category.

An alternative to the insider-outsider dichotomy is available within the framework of postcolonial literary theory as a perspective from which to examine fiction from the Pacific. The idea of a postcolonial literary theory $^{2}$ emerged from the inability of European theory to deal adequately with the complexities and varied cultural contexts of postcolonial writing. Postcolonial theory is a term for a loose body of theoretical and critical approaches used to examine the cultures of former colonies of European empires. While no single method or proposition defines postcolonial theory, it is generally based on several assumptions, the most important of which, perhaps, is that the way to begin reading postcolonial literatures is to examine the writers' treatment of the consequences of colonization: displacement, hybrid cultures, fragmented selves, and marginal voices. The postcolonial perspective assumes that place of residence or nationality or native language does not produce privileged or complete understanding. No simple binary distinction of native-nonnative, insider-outsider, home-away, same-different can adequately express the decentered reality of postcolonial literatures, because such distinctions stem from the discredited hierarchical colonial structure of Self-Other, which is based on the view that the colonizing presence emanates from the center of power, culture, and civilization, while the colonies are outside, on the periphery of that center. The center's aim in colonization is to bring those "others" into conformity with the defining center. 
Ashcroft, Griffiths, and Tiffin made the point that one of the main features of imperial control in the colonies was through language: "The imperial education system installs a standard version of the imperial language as norm and marginalizes all variants and impurities. Language then becomes the medium through which imperial power is perpetuated. However, such power is rejected when an effective post-colonial voice emerges" (I989, 7-8).

Early writing from the Pacific used Standard English. However, more recent writings from the Pacific have embodied a postcolonial identity through their use of a variant form of Standard English that itself symbolizes the postcolonial stance of resisting the imposition of a prescribed usage by any authority or center of power.

\section{Elements of Postcoloniality in Fiction FROM THE PACIFIC}

Recent fiction from the Pacific embodies its postcolonial identity through the perspective it adopts, through its innovations in language use, and through its ability to transform traditional images of society and culture into images of postcoloniality. Samoa has produced significant fiction that challenges the insider-outsider based perspective on life in the Pacific. Sia Figiel's recent novel about a young girl coming of age in Samoa, Where We Once Belonged, clearly emanates from a postcolonial perspective (I996). Commenting on her island context, Figiel presents a narrative voice that seems to step outside the images of Samoan society already in circulation, examine those images, and joke about their absurdity.

Figiel weaves an in-crowd, running joke through her narrator, Alofa, who makes gossipy allusions to Margaret Mead and Derek Freeman. ${ }^{3}$ Alofa casually confides that a Samoan woman who was interviewed on the subjects of sex, status, and domestic violence by a palagi (Caucasian) man and woman - the woman had lived on Ta'u sixty years earlier-subsequently named her twin sons, Freeman and Derek. Both sons turned out to be men "after the manner of women" (fa'afafige), who were then excluded from their mother's life and her prayers because of their lives of sin. In another passage, Mead and Freeman are again poked fun at when Alofa tells about her teacher at Samoa High School who showed the class a Time magazine article about Samoa and the Mead-Freeman controversy. Alofa comments that "none of us knew what the Mead-Freeman controversy was. None of us knew what the word controversy meant" 
(Figiel I996, 204). Later Alofa asks a girl from another village to explain what the teacher had talked about in class. That girl's explanation is "that Mead was a palagi woman who wrote a book on Samoan girls doing 'it' a lot, ... that Freeman was a palagi man who said that Mead was wrong about Samoan girls doing 'it' a lot, ... and that Samoans are jealous, hateful, murderous people who do not know how to do 'it'" (Figiel I996, 204).

Alofa's subsequent recounting of the explanation to her friends, and their responses- "How did the palagi woman know that we do 'it' a lot? and What about the palagi man? What about him? How does he know that we ... I mean that people like Lili don't do it a lot?" (Figiel I996, 204) - create a powerful image of postcoloniality: a subject looking at itself as object and ridiculing the mechanism that created its object status.

Another element of postcoloniality apparent in Figiel's novel is the way the text transforms images of traditional societies and institutions that have been imposed by the colonizing center. When Alofa's American Peace Corps teacher, Miss Cunningham, gives the class an essay-writing assignment on a topic that she insists should emphasize the "I" or individual experience, Alofa writes an essay that she titles "My Family's Pet." She subsequently reflects, "I didn't know then why I didn't choose essay topic 3 ('On My Way to School Today I Saw . . .'). I knew only that it was hard to witness something alone. . . Nothing was witnessed in the 'I' form . . . 'I' does not exist, Miss Cunningham. 'I' is 'we' . . a always" (Figiel I996, I32-I33).

Alofa's words undermine Miss Cunningham's intention and surely offer empowerment and a transformed reality to readers of the text and members of Samoan society who may themselves feel pressure to mimic images of identity that are imposed from the outside. Figiel's text celebrates Alofa's difference as a sign of her power rather than as a sign of negation, as a sign of her freedom rather than her subjugation, as a sign of her creativity rather than her limitations.

The account of life in Samoa that emerges from Figiel's novel is an account that presents sights, sounds, memories, verbal expressions, and awakenings from a young girl's experience growing up in a Samoan village. The novel never presents Alofa as a victim, a passive recipient of an external force that threatens to overwhelm her. Rather, it presents Alofa's sensibility filtering reality and producing new meaning as she, in the manner of an object demanding to be another subject, examines island scenes and experiences, including elements that represent the colonial presence 
(television, pornographic magazines, Marlboros) and makes fun of the assumptions of superiority she recognizes in the discourses of the selfstyled experts on Samoan society.

Another relative latecomer to the writing scene in the Pacific is Alan Duff, who by anyone's accounting has received mixed response to his claim that he speaks from inside experience as a New Zealand Maori. Duff's point of view and the response his work has evoked-from both inside and outside the Pacific-focus the postcolonial issue of who shall speak with authority for those occupying the margins, for those who have been colonized and made invisible. In describing his reasons for writing Once Were Warriors (1990), Duff wrote in the introduction to his book Maori: The Crisis and the Challenge:

I wrote it in outrage. And quite possibly, in relief that I had not turned out as just another of the losers I portrayed. I wrote because I've lived that lifebecause I've been on the same path of aimlessness, self destruction and the destruction of others who have been innocents. I wrote ... as my best protest against that which very nearly destroyed me. And because I want to attempt an understanding of the process that makes for this dreadful disparity between the two races, Pakeha and Maori ... I write ... from a history of past failures, past wretchedness, that gives me the qualifications of first hand experience. (I993, xii-xiii)

In an interview published in Meanjin in I993, Duff tells the interviewer that he spent time in a boy's home during his youth. He is quoted as describing his background as "starkly contrasting. Maori mother, European father. Father educated, Mother uneducated. Father rational, Mother volatile" (Thompson 1993, 6). Following the publication of Once Were Warriors, Duff was often accused of being anti-Maori (Jones I993, 5). He was viewed by "establishment Maori" as attacking "the very core of Maori culture" (Thompson I994, 406). When the University of Hawai'i Press chose Warriors in 1994 for inclusion in Talanoa, its indigenous Pacific literature series, Vilsoni Hereniko, series editor, called the act of publication an honor "to a lone voice" because Duff had written from a politically incorrect position. He had challenged the widespread view that the Pakeha were responsible for conditions in which Maori people found themselves by depicting a hard-drinking, wife-beating Maori father, Jake Heke, in a way that seemed to imply that Maori themselves were largely responsible for ruined Maori lives.

Christina Thompson viewed the University of Hawai'i Press's decision 
to include Duff in their Talanoa series as suggesting that he had "temporarily at least usurped the role of representative Maori novelist" from Patricia Grace, Witi Ihimaera, or Keri Hulme. "And that," she continued, "is a radical turn indeed, for no one could be less representative of Maori writing and politics thus far, nor more problematic from almost any perspective" than Duff (I994, 399). Thompson labeled Duff "unthinking and aggressive," "dogmatic, uninformed and deeply irritating" (I994, 404). She accused him of presenting "bent accounts of both cultures," consistently rendering Maori virtues as Pakeha vices (I994, 404).

By depicting Jake as failed husband, failed father, and failed man, Duff indicts Jake's values for the failures that have resulted in social, economic, and spiritual disease in Maori society. These failures represent a movement toward death. Duff wants to demonstrate how Maori society can become whole. He wants to reconnect Maori people to a future-a way out of living for the moment and for momentary satisfactions. Duff expresses his complete break with traditional Maori views through his characterization of Beth.

Beth is revealed as one who reflects on things and tries to figure out what they mean and how they got the way they have become. She is Maori. She is a woman. And she begins the healing process in Pine Block. Beth calls herself a "traitor in her own midst" for noticing the violence and the destructive lifestyle of Maori. This perception is what Duff considers the traditional Maori view-labeling as traitors Maori who notice the violence and destructive lifestyles of Maori. By revealing her behavior as ironic, Duff demonstrates the irony of the traditional Maori view of society.

Early in the novel, Beth ponders the fate of Maori children belonging to a bookless society. But she dissociates herself from Maori even as she behaves in the same way they do. In the scene where Beth drinks to ease the pain of the beating she had from Jake the night before, she reflects on Maori love of booze and how it leads to all the other ills in Maori lifedrunken, violent behavior, not enough to eat, no comforts or finer things of life-as she downs one quart- bottle of beer after another. The irony is palpable. Nevertheless, Beth becomes the instrument of change in the novel because she has the capacity to reflect on the past and learn from it, to consider how the events of the past define the future.

By portraying a woman as the impetus for change and the source of healing within the Maori community, Duff dramatically expresses his opposition to traditional Maori views, specifically that women should not 
speak on the marae, that is, they should have no real voice in the community's affairs. By depicting Beth at the center of a new family structure that begins the healing process within the community, Duff confirms his pro-Maori bias-and transforms the hopeless futile lives of the Maori he has depicted living in Pine Block into a postcolonial image that challenges the authority of tradition.

Complicating the issue of the extent to which Duff may speak as Maori is the phenomenon of the incredible reception the film version of Once Were Warriors was accorded when it appeared in I994. The film was directed by Maori Lee Tamahori, based on a screenplay by Maori Riwia Brown, and featured Maori Rena Owen and Temuera Morrison in the leading roles. The film became New Zealand's biggest box office hit. It won numerous awards and has been distributed in more than thirty-five countries worldwide.

The film's portrayal of the unrelenting grimness and degradation of everyday life depicted in Duff's novel was softened and made more palatable by presenting Beth from the beginning with more pronounced maternal instincts and a strength to stand up to Jake that only appeared in the novel after Grace's death. The almost-universal acclaim the film received, coupled with the mixed critical reception of Duff's novel, emphasizes the extent of the conflict over how to determine which voices speak authoritatively for those living in the new Pacific.

The whole issue is thorny and fraught with difficulty. The controversy resulting from C K Stead's (I985) challenge of Keri Hulme as Maori novelist sheds some light on the question of what constitutes indigenous group membership. Stead challenged Hulme's right to call herself Maori novelist on several grounds: racial antecedents (of her eight great-grandparents, only one was Maori); language (Hulme was not brought up speaking Maori); authenticity of Maori elements in the novel (Pakeha male critic Stead judged Maori cultural elements in the novel "willed," "self-conscious," "not authentic").

Margery Fee took up Stead's challenge and argued cogently against what she termed Stead's "biological essentialism" (I989, I8) as the basis of sexism, racism, and class discrimination. Fee concluded that membership in a minority group is more likely to be established through socialization (growing up in the company of other members of the group and identified as belonging to that group) than through bloodlines or language facility. Ultimately in Fee's terms, writing should be considered indigenous if it promotes indigenous access to power without negating 
indigenous difference. But even that is no definitive answer to whether Duff speaks as Maori or as Uncle-Tom-Pakeha, since judgments about the real-world consequences of his work are so divided.

Perhaps raising the question of who can speak for indigenous peoples and considering ways of determining an answer are more important processes in postcolonial thought than reaching a final conclusion on this issue. The realm of Pacific fiction offers a complex array of works articulating multiplicitous realities; these works may best be approached in the same way that David Maughan Brown (I985) approached the novels of Ngugi wa Thiong'o, and Terry Threadgold (I988) approached a range of texts about historical murders of whites by Aboriginals in Australia. That is, one should look at everything: ideas, themes, images in writing from the most right-wing to the most left-wing, contemporary newspaper accounts, films, and other art. And it is virtually certain that all will not agree in their judgments.

Just as Alan Duff's novel Once Were Warriors depicts life in a statehousing area among Maori displaced from their indigenous roots to innercity life-on-the-dole in New Zealand, John Pule's The Shark That Ate the Sun (1992) depicts the alcohol-induced brutality and degradation that haunt the lives of another Pacific people who have transplanted themselves to urban New Zealand. Pule's novel details the lives of an extended family who have emigrated from Niue to New Zealand, one member at a time. The story is told through letters interspersed with poems, songs, passages of almost incoherent stream-of-consciousness author statement, and narrative episodes. This manner of telling the story mimics the sense of incoherence, displacement, loss of direction, and fragmented selves that characterizes the experience of transplanted Pacific Islanders.

Just as Duff's authority to speak as Maori has been contested on the grounds of his background and upbringing as well as the sheer negativity of the book, Pule's authority to speak as Niuean has been contested. Some argue that Pule can hardly write authentically about Niuean life because he has lived in New Zealand since he was two years old. However, because his work focuses on the consequences of emigrating away from his people's place of origin, others have accepted his portrayal as representative.

The Shark That Ate the Sun conveys the inchoate loss that Niueans experience in the foreign land that fuels their drinking and rootless behavior. The tone is pitiless and unrelenting. Just as Duff seemed to place responsibility for ruined Maori lives squarely on Maori, Pule places responsibility on Niueans who drink themselves to early graves and con- 
sign their families to lives of futility. Images of violence and self destruction in Pule's novel are reminiscent of images in Duff's work.

Criticism of both Duff's and Pule's novels has been concerned with their representational accuracy, that is, with the extent to which the representations in the texts correspond to given realities. But neither work has been examined with regard to its power to produce meaning rather than to reflect or express it. Both novels might more insightfully be examined as producing new meaning and images of postcolonial experience.

Postcolonial critic, Homi K Bhabha sketched the way critical commentary based on standards of representational accuracy might be rationalized (I984). Bhabha pointed out that evaluation of this kind becomes the business of judging most favorably a work that deviates least from some preexisting standard (reality) - an essentially colonial stance. Instead of approaching Duff's Warriors and Pule's Shark metaphorically and evaluating them as more or less accurate representations of reality, readers may be encouraged by Bhabha's insights to see them as metonymy-each one representing one of the myriad postcolonial experiences that stands for or emblemizes the whole.

A recent novel, Nights in the Gardens of Spain (1995), by Witi Ihimaera, who published the first Maori novel, Tangi, in I973, offers a stunning representation of postcoloniality. The novel plays out the postcolonial society's struggle against essentializing identity politics in terms of protagonist David Munro's crisis of identity and a journey that he draws the reader into through the unfamiliar landscape of the gay community (in the company of a native guide who knows the territory). All of these are recognizable elements of postcoloniality. The society's struggle is given expression through the individual's struggle.

In Tangi, Ihimaera incorporated untranslated Maori vocabulary into the text as a means of adapting Standard English to the expression of Maori culture and identity, creating a form different from the one used by the colonizers. In Nights, Ihimaera has made several striking innovations in the way he uses language to create a new form for the expression of gay culture and identity. Ihimaera's linguistic innovations in Nights include a vivid naming convention and the incorporation of idioms and motifs of fairy tales into the X-rated world of steam parlors and gay beaches.

Using a vivid naming convention he adopted for many characters in the novel, Ihimaera refers to gay friends and cohorts variously as Fat Forty and a Fairy, Always A Bridesmaid, Snake Charmer, Love of My Life, Hope Springs Eternal, and Oh My Goodness. His colleagues at university 
are known as Spinster, God's Gift to Woman, and Predator; and his lawyer, engaged to negotiate the minefield of his divorce, is The Most Boring Man in the World. In referring to characters by such names, Ihimaera avoids identifying them as Maori or Pakeha (except in the case of the Noble Savage, who is identified as Maori), perhaps implying that generally characters' cultural identities are less important than their individual personal attributes or the roles they play in the plot of the novel.

Another linguistic adaptation Ihimaera makes in the novel is the incorporation of the motifs and idiom of children's stories, which he uses to convey the incredible distance between the real life of David Munro and the expectations for "living happily ever after" that he inherited from his traditional European conservative parents. The title of part I in the novel is "One's Real Life Is Often the Life One Does Not Lead." Ihimaera maintains a running commentary on David Munro's life in terms of details and motifs from fairy tale lore and the story of Peter Pan in particular. David Munro refers to himself as The Handsome Prince, to his wife, Annabelle, as The Beautiful Princess, and to his daughters Rebecca and Miranda as his two little princesses. The house David has moved out of (in a move preliminary to telling his wife and family that he has a history of sexual experience with men), he calls Ship of Dreams. On his way home from The Steam Parlour, David stops across the street from Ship of Dreams to check on his two little princesses. "For something wicked may come this way. Something with slavering jaws to huff and puff and blow the house in. Or something bearing a red apple poisoned to send my princesses to eternal sleep. Or something with a needle to prick their fingers" (Ihimaera I995, I4).

Fairy tales are the most moral of all genres of story telling; virtue is always rewarded and greed is always punished. The use of fairy-tale language and motifs serves as commentary on David's story. These allusions suggest that for David the life he is living began as one of make believe that has now taken a darker turn but lacks the promise of a happy ending.

The use of fairy-tale language and motifs serves not only to convey David's sense of discontinuity between his life with happy family and his other life with men, but also to counter representations of gay culture as perverse or marginal by presenting contrasting moral views. David's own view-at least at the time he comes out to his father-is that "I knew my lust for men was wrong" (Ihimaera I995, 73). The fairy-tale language and motifs provide their own commentary on David's story.

David describes remembering how he came to be drawn back to a sex 
life with men after more than ten years of heterosexual marriage, and he characterizes that time as when "the clock in the crocodile began to tick again" (Ihimaera I995, 90), an allusion to the ticking clock that warns Captain Hook when the crocodile has returned to the scene to finish the meal he had begun when he ate Hook's hand in the children's story about Peter Pan (Barrie I99I). This reference suggests that David sees his own sexuality and its consequences as a trap, bounded by moral judgments and suffering, that holds him within a specific definition of self based on his sexual identity. But David formulates his choice in the novel as lying between Annabelle-happy family-monogamy and nights spent in the Gardens of Spain-promiscuity. This division of life into two clear choices is oversimplification and reveals David Munro as a character of limited vision, but one who provides the reader with a range of possibilities.

David clearly believes that his parents are selfish in their commitment to conservative commonwealth values, which they conceive of as "natural." He says that his relationships with parents have been ones in which he has said yes to them, and they have said no to him. And when David tells his father that he is gay, he notes "My father begins to weep for himself." But David exhibits the same unconscious fallacy and moral superiority when he implies that there is a genetic basis for his gayness: he thinks of his face as concealing "the real me," who suffers from a "compulsion" - "the night is a river, and I am driven to wander its banks" - and he acknowledges that he undertook a regimen of physical training "to punish myself for what I suspected I was" (Ihimaera 1995, 68, 72, I6, 244, I I 5,74$)$. Again, one is conscious of a discrepancy between David's perspective and the more complex view the novel presents.

David's tone of wonder as he admires the Maori character he calls The Noble Savage, taken in context with the novel's portrayal of that character, serves to dismantle conventional notions of Maori-ness. When David sees The Noble Savage, he thinks to himself "Today he looks brand new, as if he has just stepped out of a Gauguin painting, straight out of Eden." Later in the novel, David says that "Polynesians by virtue of their sensual natures are the best" (Ihimaera I995, I6, II8). Yet one cannot assume that these views are Ihimaera's or that they are offered as straightforward representation of reality. Rather, such comments may be interpreted as creating an ironic tone because they have been written by a writer whose work has consistently dismantled such simplistic categories of identity.

None of the aspects of fiction that Ihimaera exploits can be interpreted simply. The reality that the novel constructs (or deconstructs) is slippery 
and contradictory. Ihimaera, first Maori novelist, has created a Pakeha persona to narrate the first Pacific gay novel that dismantles notions of gayness, Maori-ness, and heterosexuality. David Munro defines his ancestors as those who have preceded him in the history of struggle for gay identity. But The Noble Savage says to David, "If I was to choose between being Maori or being gay, I would have to choose to be Maori. That is how I was born and that is how my people will bury me ... when it comes to the crunch, my cultural registration is more important than my sexual registration" (Ihimaera I995, 234).

Offering a range of possibilities in identifying people avoids the pitfalls of oversimplification. Rather than representing reality by offering truths that the gay community may have agreed on-the ones that "no one really thinks of . . . as lies when they are telling them, even when they do not correspond to the lives they are living" (Bacon I998, 254)-Ihimaera has constructed a postcolonial novel that calls itself fiction but tells the truth even if it didn't happen.

In light of Ihimaera's widely accepted position in New Zealand as Maori novelist, Nights in the Gardens of Spain raises questions again of who can speak for Maori, for Pakeha, and for members of the gay community and on which marae (area in front of a Maori meetinghouse where official proceedings take place) they can be heard. Whatever David Munro discovers about himself and his sexuality in the course of the novel is filtered through and conditioned by his own sensibility. Readers, however, envision a more complex reality than the one articulated by David Munro because Ihimaera has exploited elements of postcoloniality to present images of outsiders that have moved I 80 degrees from his early pastoral depiction of Maori characters. Through these radical images of outsider, this novel again speaks from the margins, in the voice of an "other," just as Ihimaera's early Maori novels did.

These recent works of fiction from the Pacific, and others collected and published in Mānoa (1993; I997) and in Wasafiri (1997) extend the boundaries of a postcolonial form that began to emerge in works written in the I970s by Wendt, Ihimaera, Grace, and Hulme. Recent works by Duff, Figiel, Ihimaera, and Pule raise modern issues of contested identities, social constructions of reality, and arguments about who is empowered to speak for peoples living in the new Pacific. To continue the discourse is to continue to construct new realities and to promote "other" access to power by celebrating difference. 


\section{Notes}

I Authentic is Sharrad's term to distinguish what he called "modern literary outpouring" written by the Islanders themselves from literary writing about the Pacific by visitors and foreign settlers.

2 Leading postcolonial theorists agree that the common ground they share is their response to the depiction of the colonized as always situated as "other" and unable to assume the necessary role as self. Prominent postcolonial theorists include Edward Said (I978); Homi K Bhabha (I983); Gayatri Chakravorty Spivak (I987); and the "Empire Writes Back" school that includes Bill Ashcroft, Gareth Griffiths, and Helen Tiffin (I989). The Empire Writes Back takes its name from Salman Rushdie's piece "The Empire Strikes Back with a Vengeance," and emphasizes what it terms "hybridization," through which indigenous traditions combine with imperial remnants to create something newly postcolonial.

3 In I928, when Margaret Mead published Coming of Age in Samoa, based on three months' fieldwork on Ta'u in American Samoa, she announced her discovery of a culture where the stress of adolescence did not exist. That book became the best-selling anthropology text of all time. It continued to represent a "negative instance" within the nature-nurture controversy, used to "prove" the superiority of culture over heredity until I983, when Derek Freeman challenged Mead's depiction of Samoan character in his book Margaret Mead and Samoa. Contrary to Mead's claims that Samoan society featured permissive child rearing and tolerant sexual attitudes, Freeman claimed that adolescence in Samoa is a time of frequent stress in an authoritarian society with strong forms of punishment in child rearing and severe sanctions against premarital sex.

\section{References}

Ashcroft, Bill, Gareth Griffiths, and Helen Tiffin

I989 The Empire Writes Back: Theory and Practice in Post-Colonial Literatures. London: Routledge.

Bacon, Jen

I998 Getting the Story Straight: Coming Out Narratives and the Possibility of a Cultural Rhetoric. World Englishes I7 (2): 249-258.

Barrie, J M

I99I Peter Pan, illustrated by Scott Gustafson. New York: Viking. First published 1906.

Bhabha, Homi K

I984 Representation and the Colonial Text: A Critical Exploration of Some Forms of Mimeticism. In The Theory of Reading, edited by Frank Gloversmith, 93-I22. Brighton: Harvester.

I994 The Location of Culture. London and New York: Routledge. 
Duff, Alan I990 Once Were Warriors. Auckland: Tandem.

I993 Maori: The Crisis and the Challenge. Auckland: HarperCollins.

Eri, Vincent

I970 The Crocodile. Auckland: Longman Paul.

Fee, Margery

I989 Why C K Stead Didn't Like Keri Hulme's The Bone People: Who Can Write as Other? Australian and New Zealand Studies in Canada I:I I-32.

Figiel, Sia

I996 Where We Once Belonged. Auckland: Pasifika Press.

Freeman, Derek

I983 Margaret Mead and Samoa. Cambridge: Harvard University Press.

Grace, Patricia

I975 Waiariki. Auckland: Longman Paul.

I992 Cousins. Auckland: Penguin.

Hulme, Keri

I985 The Bone People. Auckland: Spiral Collective and Hodder \& Stoughton. Reprinted by Penguin Books, New York.

Ihimaera, Witi

I972 Pounamu Pounamu: Auckland: Heinemann.

I973 Tangi. Auckland: Heinemann.

I995 Nights in the Gardens of Spain. Auckland: Secker and Warburg.

Jones, Lloyd

I993 Advice from Lone Voice. Interview in New Zealand Herald, 24 April.

Kiki, Albert Maori

I968 Kiki: Ten Thousand Years in a Lifetime. Melbourne: Cheshire.

Mānoa: A Pacific Journal of International Writing

I989- Honolulu: University of Hawai'i Press.

Maughan Brown, David A

I985 Land, Freedom and Fiction: History and Ideology in Kenya. London: Zed Books.

Mead, Margaret

I928 Coming of Age in Samoa. New York: Mentor.

Minh-ha, Trinh T

I995 No Master Territories. In The Post-Colonial Studies Reader, edited by Bill Ashcroft, G Griffiths, and Helen Tiffin, 21 5-218. New York and London: Routledge.

Pule, John

I992 The Shark That Ate the Sun. Auckland: Penguin.

Said, Edward

I978 Orientalism. London: Routledge \& Kegan Paul. 
Sharrad, Paul

I990 Imagining the Pacific. Meanjin 4:597-606.

Sharrad, Paul, editor

I993 Readings in Pacific Literature. Wollongong: New Literatures Research Centre, University of Wollongong.

Spivak, Gayatri Chakravorty

I987 In Other Worlds: Essays in Cultural Politics. New York: Methuen.

Stead, C K

I985 Keri Hulme's The Bone People and the Pegasus Award for Maori Literature. Ariel I6:IOI-IO8.

Subramani

I985 South Pacific Literature: From Myth to Fabulation. Suva: Institute of Pacific Studies, University of the South Pacific.

Sullivan, Jane

I99I His Tale Aims to Restore Warrior Pride. Interview in Age (Melbourne), 2I September, 8.

Thompson, Christina

I994 In Whose Face? An Essay on the Work of Alan Duff. The Contemporary Pacific 6:398-4I3.

I995 Alan Duff: The Book, the Film, the Interview. Meanjin 54 (I): 6-I3.

Threadgold, Terry

I988 Stories of Race and Gender: An Unbounded Discourse. In Functions of Style, edited by D Birch and M O'Toole, I69-20I. London: Pinter.

Wasafiri. Semiannual published by University of London.

Wendt, Albert

1973 Sons for the Return Home. Auckland: Longman Paul.

I980 Lali: An Anthology of Pacific Writings. Auckland: Longman Paul.

I995 Nuanua: Pacific Writing in English since I980. Auckland: Auckland University Press.

\section{Abstract}

Historically, the perspective assumed in writing about the Pacific until I970 presented Pacific peoples through European eyes in roles of spectators and objects of European desires. After the beginning of what Paul Sharrad called an "authentic" Pacific literature, the perspective shifted to one that viewed life through the eyes of Pacific peoples. For example, "Parade" by Patricia Grace can be read as a trope of the transforming power of the insider perspective. When the insider perspective is examined in postcolonial terms, it is clear that "there can hardly 
be such a thing as an essential inside that can be homogeneously represented by all insiders" (Minh-ha I995, 218). The realities of contemporary writers from the Pacific illustrate the complications in claiming privilege for Pacific voices because they are native. New fiction from the Pacific during the I990s exhibits its postcolonial identity through the perspectives it adopts, through innovations in language use, and through its ability to transform traditional images of society and culture into images of postcoloniality.

KEYWORDs: Alan Duff, contemporary Pacific fiction, Sia Figiel, Witi Ihimaera, Maori writers, postcolonial writing, Samoan writers, John Pule 